\title{
UJI PERKECAMBAHAN BENIH PADI LOKAL JAWA BARAT AKIBAT PEMBERIAN GIBERELIN PADA KONDISI CEKAMAN RENDAMAN
}

\section{WEST JAVA LOCAL RICE SEED GERMINATION TEST DUE TO PROVISION OF GIBERELIN IN SOAKING STRESS CONDITIONS}

\author{
Roni Assafaat Hadi ${ }^{*}$ \\ ${ }^{1}$ Jurusan Agroteknologi, Fakultas Pertanian, Universitas Winaya Mukti \\ Jl. Raya Bandung - Sumedang km.29 Tanjungsari, Kab.Sumedang 45362 \\ *Korespondensi: roni.assafaat.hadi@gmail.com \\ Diterima / Disetujui
}

\begin{abstract}
ABSTRAK
Upaya peningkatan produksi beras Nasional dihadapkan pada masalah cekaman biotik dan abiotik yang dapat mengganggu pertumbuhan dan hasil tanaman padi. Varietas padi tahan rendaman dibutuhkan untuk mengantisipasi terjadinya penurunan hasil akibat banjir. Penelitian ini mengkaji pengaruh konsentrasi giberelin terhadap perkecambahan padi lokal Jawa Barat pada kondisi cekaman rendaman. Berdasarkan hasil penelitian dan pembahasan yang telah diuraikan pada sebelumnya, maka dapat ditarik kesimpulan terhadap perkecambahan padi lahan rawan banjir, diantaranya Konsentrasi giberelin $10 \mathrm{mg} . \mathrm{L}^{-1}$ memberikan hasil terbaik pada pengamatan untuk masing-masing varietas lokal mesir. Varietas tanaman padi secara mandiri berpengaruh terhadap jumlah kecambah umur 14 HST (hari setelah tanam), dan vigor benih.
\end{abstract}

Kata Kunci : giberelin, perkecambahan padi, varietas padi lokal

\begin{abstract}
Efforts to increase national rice production are faced with biotic and abiotic stress problems that can interfere with the growth and yield of rice plants. Soaking resistant rice varieties are needed to anticipate the decline in yields due to flooding. This study examines the influence of gibberellins concentration on local germination of West Java rice in soaking stress conditions. Based on the results of research and discussion described previously, conclusions can be drawn towards the germination of rice prone to flooding, the concentration of gibberellins $10 \mathrm{mg}^{\mathrm{L}} \mathrm{L}^{-1}$ gives the best results on observations for each of the local varieties of egypt. Rice varieties independently affect the number of seedlings aged 14 DAP (days after planting), and seed vigor.
\end{abstract}

Keywords: giberelin, local rice varieties, rice germination

\section{PENDAHULUAN}

Beras merupakan makanan pokok masyarakat di Indonesia. Kebutuhan akan beras bagi Indonesia dari tahun ke tahun akan semakin meningkat seiring dengan pertambahan jumlah penduduk. Estimasi laju pertumbuhan penduduk Indonesia pada rentang waktu 2005 - 2010 adalah 1,3\% dengan jumlah penduduk 233,48 juta jiwa dan tingkat konsumsi beras bruto 139,5 kg per kapita, maka kebutuhan beras mencapai 32,49 juta ton. Untuk mengantisipasi penambahan jumlah 
penduduk tersebut, maka Indonesia setidaknya harus menambah ketersediaan beras nasional hingga tujuh juta ton pada 2025 - 2030 (Direktorat Jenderal Prasarana dan Sarana Pertanian, 2013).

Upaya peningkatan produksi beras Nasional dihadapkan pada masalah cekaman biotik dan abiotik yang dapat mengganggu pertumbuhan dan hasil tanaman padi. Rendaman air merupakan salah satu faktor pembatas utama peningkatan produksi padi di lahan rawan banjir, sedangkan sentra produksi padi di Jawa Barat sebagian besar berada pada wilayah rawan banjir. Perubahan iklim global yang menyebabkan meningkatnya frekuensi banjir di berbagai wilayah dapat mengancam stabilitas produksi beras Nasional (Aris Hairmansis et al., 2012).

Banjir mempengaruhi komposisi kandungan protein dalam akar. Varietas padi yang peka terhadap banjir akan mengalami kerusakan setelah terendam banjir selama satu minggu. Varietas toleran dengan gene SUB1 toleran terhadap banjir mulai umur satu minggu setelah semai sampai dua minggu sebelum berbunga (Mackill et al., 2012). Tanaman toleran banjir menunjukkan fotosintesis yang tetap tinggi, kandungan air bebas dan efisiensi pemakaian air tinggi pada hantaran daun dan potensial air daun yang rendah, kandungan klorofil rendah sehingga absorpsi cahaya rendah sehingga tidak terjadi kerusakan sistem fotosintesis oleh fotooksidasi, kandungan protein bebas rendah karena lebih banyak sintesa bahan untuk ketahanan terhadap banjir, struktur daun dan epidermis tidak rusak, dapat menghindari kekurangan oksigen (Du et al., 2012).

Varietas padi tahan rendaman dibutuhkan untuk mengantisipasi terjadinya penurunan hasil akibat banjir. Berbagai penelitian varietas dilaksanakan dalam upaya mengatasi penurunan produksi akibat banjir seperti menciptakan varietas-varietas padi tahan rendaman seperti Inpara 3, Inpara 4 dan Inpara 5, tetapi penting juga untuk mengetahui tingkat kekuatan atau toleransi daripada padi - padi lokal terhadap rendaman banjir.

$$
\text { Sejak sekitar tahun 1955, }
$$
giberelin telah diketahui dapat mendorong perkecambahan benih. Giberelin dapat mengganti fungsi dari kebutuhan akan cahaya dan temperatur dalam mendorong perkecambahan. Giberelin dipercaya sangat penting untuk mengontrol perkecambahan benih secara alami (Copeland, 1978). Respon tanaman terhadap giberelin yang sering muncul adalah pemanjangan batang. Pada beberapa tanaman, giberelin menginduksi pembungaan dan membuat tanaman kerdil memiliki pertumbuhan 
yang normal, memacu pematahan dormansi biji dan efek buah partenokarpi (Salisbury, 1957). Ditambahkan efek giberelin ini terlihat lebih berpengaruh dalam kondisi stress.

Untuk mengetahui kemampuan tumbuh dan kemampuan adaptasi dengan lingkungan pada lahan rawan banjir, pengujian terhadap ketahanan varietas padi lokal Jawa Barat dan responnya terhadap pemberian giberelin $\left(\mathrm{GA}_{3}\right)$ pada kondisi cekaman rendaman mutlak diperlukan, karena kemampuan tumbuh atau penampilan tanaman secara keseluruhan merupakan cerminan pengaruh genetik dan fenotipik selama proses perkembangan tanaman yang bersangkutan.

\section{BAHAN DAN METODE}

Penelitian ini mengkaji pengaruh konsentrasi giberelin $\left(\mathrm{GA}_{3}\right)$ terhadap perkecambahan, pertumbuhan serta komponen hasil padierbagai varietas padi local Jawa Barat pada lahan rawan banjir. Berdasarkan tujuan tersebut maka sifat dari penelitian ini adalah verifikatif dilakukan dengan pendekatan eksperimen di laboratorium dan di lapangan.

Penelitian dilaksanakan di Rumah Kaca dan lapangan kebun produksi Fakultas Pertanian Universitas Winaya Mukti Tanjungsari - Sumedang, dengan ketinggian tempat $850 \mathrm{~m} \mathrm{dpl}$.
Eksperimen menggunakan Rancangan Acak Kelompok (RAK) pola faktorial, yang terdiri dari dua faktor yaitu empat taraf konsentrasi giberelin dan lima taraf varietas padi sawah. Tiap perlakuan diulang sebanyak dua kali, maka jumlah keseluruhan: 4 × 5 × $2=40$ plot.

Respon perkecambahan dan pertumbuhan tanaman dalam rangka menguji hipotesis, dilakukan analisis varians (uji F) dengan model linier Rancangan Acak Kelompok (RAK) pola faktorial yang dikemukakan oleh warsa \& Cucu (1982), sebagai berikut :

$Y_{\mathrm{ijk}}=\mu+\mathrm{r}_{\mathrm{i}}+\mathrm{p}_{\mathrm{j}}+\mathrm{v}_{\mathrm{k}}+(\mathrm{pv})_{\mathrm{jk}}+\varepsilon_{\mathrm{ijk}}$

\section{HASIL DAN PEMBAHASAN}

Hasil yang telah dicapai terbagi pada hasil respons pengamatan penunjang dan hasil respons pengamatan utama, dimana :

\section{Respons Penunjang}

Pengamatan penunjang dalam percobaan ini meliputi suhu selama percobaan di screen house dan di lapangan, kelembaban udara di screen house dan di lapangan, serangan hama dan penyakit pada saat perkecambahan dan pertumbuhan, serta gulma yang tumbuh dominan baik pada saat perkecambahan maupun pada saat pertumbuhan tanaman.

Keadaan suhu udara rata-rata selama percobaan suhu udara rata-rata 
di dalam screen house adalah $24{ }^{\circ} \mathrm{C}$ dan kelembaban udara relatifnya adalah ratarata $81,2 \%$. Sedangkan suhu udara ratarata di lapangan adalah $23{ }^{\circ} \mathrm{C}$ dan kelembaban udara relatifnya adalah ratarata $82,2 \%$.

Selama percobaan berlangsung ada beberapa gulma yang tumbuh di areal percobaan baik pada saat percobaan perkecambahan maupun pada percobaan pertumbuhan. Pada percobaan perkecambahan muncul gulma semanggi (Marsilea crenata), penanggulangannya dengan cara melakukan penyiangan setiap tiga hari sekali.

\section{Respons Utama}

Respons utama atau pengamatan utama adalah pengamatan yang datanya digunakan untuk menjawab hipotesis, yang meliputi : jumlah kecambah, vigor benih, panjang akar kecambah, panjang pupus kecambah, bobot kering kecambah, tinggi tanaman, jumlah anakan per rumpun, dan nisbah pupus akar.

\section{a. Jumlah Kecambah}

Hasil perhitungan analisis sidik ragam mengenai jumlah kecambah, tidak terjadi interaksi antara berbagai varietas padi lokal Jawa Barat dan tingkatan konsentrasi giberelin $\left(\mathrm{GA}_{3}\right)$ terhadap jumlah kecambah pada umur 7 HST.

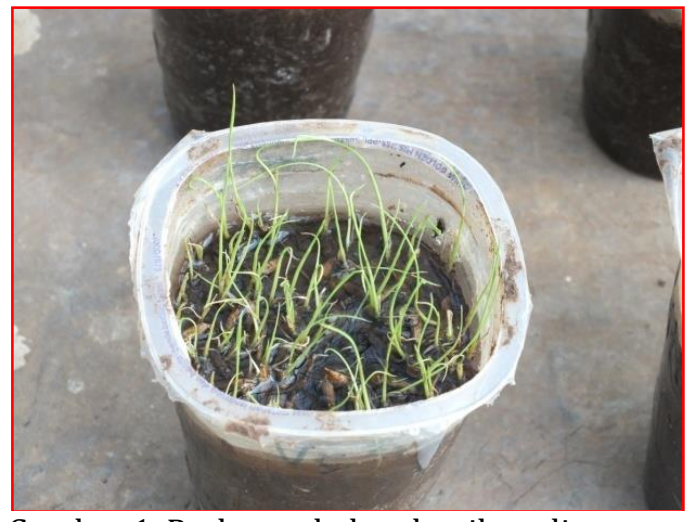

Gambar 1. Perkecambahan benih padi.

Begitu juga dengan perlakuan secara mandiri, baik perlakuan tingkatan konsentrasi giberelin $\left(\mathrm{GA}_{3}\right)$ maupun berbagai varietas padi lokal Jawa Barat tidak menunjukkan pengaruh yang nyata terhadap jumlah kecambah. Hal ini disebabkan setiap perlakuan tingkatan konsentrasi giberelin $\left(\mathrm{GA}_{3}\right)$ maupun berbagai varietas padi lokal Jawa Barat belum terlihat efeknya pada umur perkecambahan 7 HST. Untuk lebih jelasnya pengaruh perlakuan tingkatan konsentrasi giberelin $\left(\mathrm{GA}_{3}\right)$ maupun berbagai varietas padi lokal Jawa Barat terhadap jumlah kecambah pada cekaman salinitas tinggi dapat dilihat pada Tabel 1.

Setelah terjadi penyerapan air, enzim diaktifkan dan masuk ke dalam endosperm dan terjadi perombakan zat cadangan makanan. Enzim amilase merombak pati menjadi glukosa, enzim lipase merombak lemak menjadi asam lemak dan gliserol, sedangkan enzim protease merombak protein menjadi asam amino. Senyawa-senyawa 
sederhana ini akan diangkut ke embrio untuk pertumbuhan. Selain itu dari aktivitas kerja enzim protease akan dihasilkan asam amino yang berguna untuk pembentukan protein baru misalnya $\alpha$ amilase. Apabila enzim $\alpha$ amilase semakin meningkat maka proses hidrolisis amilum menjadi gula sederhana dapat berlangsung lebih cepat. Pembentukan $\alpha$ amylase juga dipengaruhi oleh giberelin yang ada dalam embrio. Pada awal perkecambahan asam giberelin diaktifkan untuk membentuk $\alpha$ amylase (Gardner et al., 1991). Organ pertama yang muncul dari biji yang berkecambah adalah radikula, yaitu akar embrionik. Berikutnya, ujung tunas harus menembus permukaan tanah. Pada kacang ladang dan banyak tumbuhan dikotil lainnya, hipokotil akan membentuk seperti suatu kait, dan pertumbuhan akan mendorong kait itu ke atas permukaan tanah (Campbell, 2002).

Tabel 1. Pengaruh Berbagai Varietas Padi Lokal Jawa Barat dan Tingkatan Konsentrasi Giberelin $\left(\mathrm{GA}_{3}\right)$ terhadap Jumlah Kecambah Pada Umur 7 HST

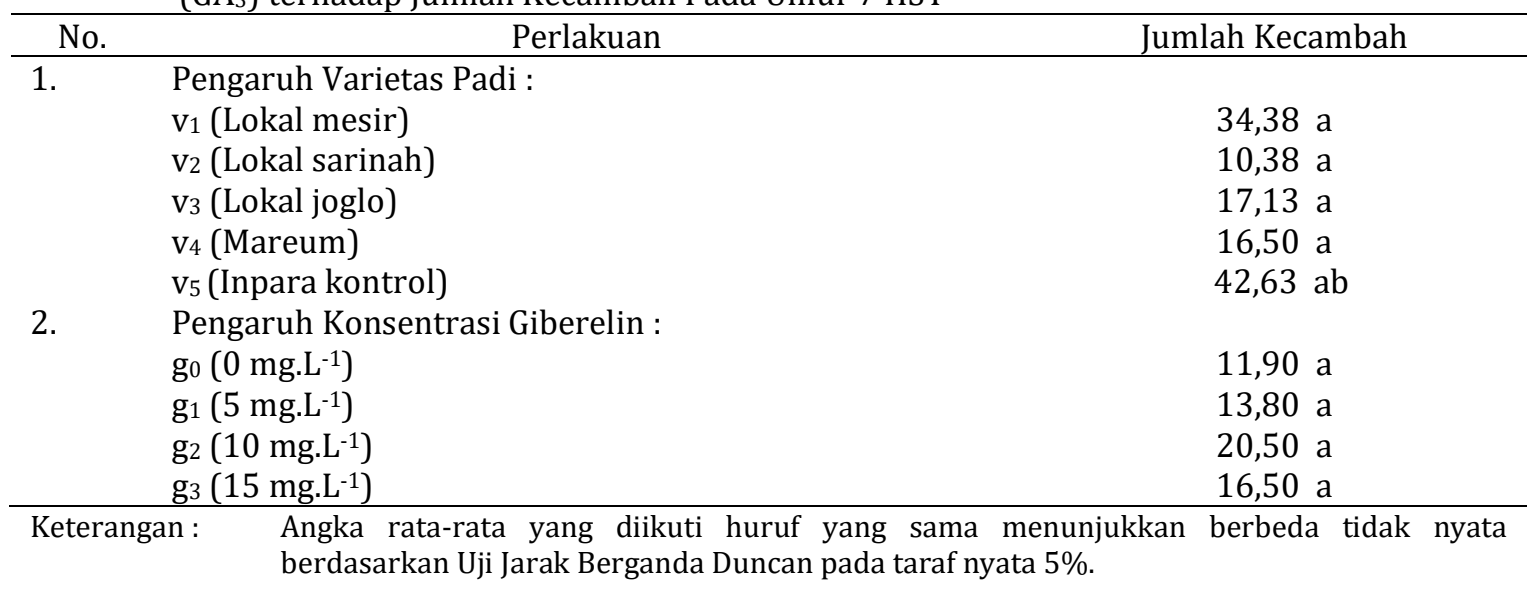

Jika dilihat dari hasil perhitungan perlakuan berbagai tingkatan konsentrasi giberelin $\left(\mathrm{GA}_{3}\right)$ diperoleh hasil tidak berpengaruh nyata untuk tingkatan konsentrasi giberelin $0 \mathrm{mg} . \mathrm{L}^{-1}$ (g0), 5 mg.. $\mathrm{L}^{-1}, 10 \mathrm{mg} . \mathrm{L}^{-1}$, dan $15 \mathrm{mg} . \mathrm{L}^{-1}$ dengan berbagai varietas padi local Jawa Barat, tetapi hanya memberikan pengaruh mandiri pada masing-masing perlakuan. Pelakuan yang memberikan pengaruh tertinggi ditunjukan oleh varietas inpara kontrol (v5).

Hasil perhitungan analisis sidik ragam mengenai jumlah kecambah pada umur 14 HST, tidak terjadi interaksi antara berbagai varietas padi lokal Jawa Barat dan tingkatan konsentrasi giberelin $\left(\mathrm{GA}_{3}\right)$ terhadap jumlah kecambah pada umur 14 HST. 
Tabel 2. Pengaruh Berbagai Varietas Padi Lokal Jawa Barat dan Tingkatan Konsentrasi Giberelin (GA3) terhadap Jumlah Kecambah Pada Umur 14 HST

\begin{tabular}{|c|c|c|}
\hline No. & Perlakuan & Jumlah Kecambah \\
\hline \multirow[t]{6}{*}{1.} & Pengaruh Varietas Padi : & \\
\hline & $\mathrm{v}_{1}$ (Lokal mesir) & $46,38 \mathrm{c}$ \\
\hline & $\mathrm{v}_{2}$ (Lokal sarinah) & 20,75 a \\
\hline & v3 (Lokal joglo) & 28,38 a \\
\hline & $\mathrm{v}_{4}$ (Mareum) & $36,88 \mathrm{~b}$ \\
\hline & v5 (Inpara kontrol) & $48,88 \mathrm{c}$ \\
\hline \multirow[t]{5}{*}{2.} & Pengaruh Konsentrasi Giberelin : & \\
\hline & $\mathrm{g}_{0}\left(0 \mathrm{mg} \cdot \mathrm{L}^{-1}\right)$ & $25,90 \mathrm{a}$ \\
\hline & $\mathrm{g}_{1}\left(5 \mathrm{mg} . \mathrm{L}^{-1}\right)$ & $24,10 \mathrm{a}$ \\
\hline & $\mathrm{g}_{2}\left(10 \mathrm{mg} \cdot \mathrm{L}^{-1}\right)$ & 29,30 a \\
\hline & $\mathrm{g}_{3}\left(15 \mathrm{mg} \cdot \mathrm{L}^{-1}\right)$ & $26,60 \mathrm{a}$ \\
\hline
\end{tabular}

Pada pengamatan jumlah kecambah umur 14 HST diperoleh bahwa hasil perhitungan perlakuan berbagai tingkatan konsentrasi giberelin $\left(\mathrm{GA}_{3}\right)$ diperoleh hasil tidak berpengaruh nyata untuk tingkatan konsentrasi giberelin 0 mg.L-1 (g0), 5 mg.L-1 10 mg.L-1 ${ }^{-1}$ dan 15 mg. $L^{-1}$ dengan berbagai varietas padi local Jawa Barat, tetapi hanya memberikan pengaruh mandiri pada masing-masing perlakuan. Pelakuan yang memberikan pengaruh tertinggi ditunjukan oleh varietas inpara kontrol (v5).

\section{b. Vigor Benih}

Hasil perhitungan analisis sidik ragam mengenai vigor benih, tidak terjadi interaksi antara berbagai varietas padi lokal Jawa Barat dan tingkatan konsentrasi giberelin $\left(\mathrm{GA}_{3}\right)$ terhadap jumlah kecambah pada umur 14 HST. Vigor benih menunjukkan kemampuan tumbuh benih pada kondisi yang suboptimum. Perlakuan yang diberikan hanya memberikan pengaruh mandiri pada masing-masing perlakuan. Pelakuan yang memberikan pengaruh tertinggi ditunjukan oleh varietas inpara kontrol (v5).

Begitu juga dengan perlakuan secara mandiri, baik perlakuan konsentrasi giberelin maupun berbagai varietas padi lokal Jawa Barat tidak menunjukkan pengaruh yang nyata terhadap vigor benih. Hal ini disebabkan setiap tingkatan konsentrasi giberelin maupun berbagai berbagai varietas padi lokal Jawa Barat belum terlihat efeknya pada umur perkecambahan 14 HST. Untuk lebih jelasnya pengaruh konsentrasi giberelin dan varietas padi sawah terhadap vigor benih pada cekaman genangan dapat dilihat pada Tabel 3. 
Tabel 3. Pengaruh Berbagai Varietas Padi Lokal Jawa Barat dan Tingkatan Konsentrasi Giberelin $\left(\mathrm{GA}_{3}\right)$ terhadap Vigor Benih Pada Umur 14 HST

\begin{tabular}{|c|c|c|}
\hline No. & Perlakuan & Vigor Benih (\%) \\
\hline \multirow[t]{6}{*}{1.} & Pengaruh Varietas Padi : & \\
\hline & V1 (Lokal mesir) & $69 \mathrm{~b}$ \\
\hline & $\mathrm{v}_{2}$ (Lokal sarinah) & $24 \mathrm{~b}$ \\
\hline & $\mathrm{V}_{3}$ (Lokal joglo) & $34 \mathrm{a}$ \\
\hline & $\mathrm{V}_{4}$ (Mareum) & $35 \mathrm{a}$ \\
\hline & V5 (Inpara kontrol) & $85 \mathrm{~b}$ \\
\hline \multirow[t]{5}{*}{2.} & Pengaruh Konsentrasi Giberelin : & \\
\hline & $\mathrm{g}_{0}\left(0 \mathrm{mg} \cdot \mathrm{L}^{-1}\right)$ & $24 \mathrm{a}$ \\
\hline & $\mathrm{g}_{1}\left(5 \mathrm{mg} \cdot \mathrm{L}^{-1}\right)$ & $28 \mathrm{a}$ \\
\hline & $\mathrm{g}_{2}\left(10 \mathrm{mg} \cdot \mathrm{L}^{-1}\right)$ & $45 \mathrm{a}$ \\
\hline & $\mathrm{g}_{3}\left(15 \mathrm{mg} \cdot \mathrm{L}^{-1}\right)$ & $33 \mathrm{a}$ \\
\hline
\end{tabular}

\section{c. Panjang Pupus Kecambah}

Hasil perhitungan analisis sidik ragam mengenai panjang pupus kecambah, tidak terjadi interaksi antara berbagai varietas padi lokal Jawa Barat dan tingkatan konsentrasi giberelin $\left(\mathrm{GA}_{3}\right)$ terhadap panjang pupus kecambah pada umur 14 HST.

Begitu juga dengan perlakuan secara mandiri, baik perlakuan berbagai varietas padi lokal Jawa Barat maupun tingkatan konsentrasi giberelin $\left(\mathrm{GA}_{3}\right)$ tidak menunjukkan pengaruh yang nyata terhadap vigor panjang pupus kecambah.

Tabel 5. Pengaruh Berbagai Varietas Padi Lokal Jawa Barat dan Tingkatan Konsentrasi Giberelin $\left(\mathrm{GA}_{3}\right)$ terhadap Panjang Pupus Kecambah Pada Umur 14 HST

\begin{tabular}{|c|c|c|}
\hline No. & Perlakuan & Panjang Pupus Kecambah (cm) \\
\hline \multirow[t]{6}{*}{1.} & Pengaruh Varietas Padi : & \\
\hline & V1 (Lokal mesir) & $14,21 \mathrm{a}$ \\
\hline & v2 (Lokal sarinah) & $16,76 \mathrm{a}$ \\
\hline & V3 (Lokal joglo) & 15,46 a \\
\hline & $\mathrm{V}_{4}$ (Mareum) & 17,04 a \\
\hline & V5 (Inpara kontrol) & 15,66 a \\
\hline \multirow[t]{5}{*}{2.} & Pengaruh Konsentrasi Giberelin : & \\
\hline & $\mathrm{g}_{0}\left(0 \mathrm{mg} \cdot \mathrm{L}^{-1}\right)$ & $11,72 \mathrm{a}$ \\
\hline & $\mathrm{g}_{1}\left(5 \mathrm{mg} \cdot \mathrm{L}^{-1}\right)$ & $10,46 \mathrm{a}$ \\
\hline & $\mathrm{g}_{2}\left(10 \mathrm{mg} \cdot \mathrm{L}^{-1}\right)$ & $14,55 \mathrm{a}$ \\
\hline & $\mathrm{g}_{3}\left(15 \mathrm{mg} \cdot \mathrm{L}^{-1}\right)$ & $14,05 \mathrm{a}$ \\
\hline
\end{tabular}


Meskipun menurut Brian and Hemming (1955), giberelin mampu merubah tanaman yang kerdil menjadi tinggi tetapi hal itu tidak berlaku untuk fase perkecambahan, terutama untuk panjang pupus kecambah. Hal ini kemungkinan disebabkan oleh kandungan giberelin banyak terdapat pada tanaman masih muda (Salisbury and Cleon, 1995) sehingga proses pemanjangan kecambah hanya memanfaatkan hormon pertumbuhan terutama giberelin yang ada pada tanaman muda tersebut tanpa mengambil giberelin tambahan yang diberikan.

\section{KESIMPULAN DAN SARAN}

\section{Kesimpulan}

Berdasarkan hasil penelitian dan pembahasan yang telah diuraikan pada sebelumnya, maka dapat ditarik kesimpulan antara berbagai varietas padi lokal Jawa Barat dan tingkatan konsentrasi giberelin $\left(\mathrm{GA}_{3}\right)$ terhadap padi cekaman genangan terhadap perkecambahan tanaman padi yaitu konsentrasi giberelin (g2) 10 mg..-1 memberikan hasil terbaik pada pengamatan untuk masing-masing varietas lokal mesir (v1) dan varietas tanaman padi secara mandiri berpengaruh terhadap jumlah kecambah umur 14 HST (hari setelah tanam), dan vigor benih.
Saran

Berdasarkan kesimpulan tersebut di atas maka dapat dikemukakan yaitu disarankan untuk mencari konsentrasi giberelin dan varietas padi lokal Jawa Barat yang terbaik, diperlukan penelitian lebih lanjut mengenai pengaruh konsentrasi giberelin dengan tingkat genangan atau rendaman, dengan konsentrasi giberelin yang lebih variatif, tingkat volume genangan atau rendaman yang lebih variatif dan penggunaan varietas padi yang lebih lengkap, dan perlu penelitian lebih lanjut dengan meggunakan ZPT (Zat Pengatur Tumbuh) yang lain selain giberelin untuk mencari hasil terbaik sebagai upaya peningkatan produksi di lahan rawan banjir.

\section{DAFTAR PUSTAKA}

Badan Penelitian dan Pengembangan Pertanian. (2013). Deskripsi varietas unggul baru padi. Sukamandi: Balibangtan Kementerian Pertanian.

Brian, P. W., \& Hemming, H. G. (1955). The Effect of Gibberellic Acid on Shoot Growth of Pea Seedlings. Physiologia Plantarum 8(3), 669 681.

Campbell, N. A. (2002). Biologi Jilid 2. Jakarta: Erlangga.

Copeland, L. O. (1978). Seed Germination. Principles of Seed Science and Technology 4 : 7. Minneapolis Minnesota: Burgess Publishing Company.

Direktorat Jenderal Prasarana dan Sarana Pertanian. (2013). Kajian Potensi Lahan Untuk Perluasan 
Tanaman Padi Sawah. Dirjen Prasarana dan Sarana Pertanian, Kementerian Pertanian Republik Indonesia.

Gardner, F. P., Pearce, R. B., \& Mitchell, R. L. (1991). Fisiologi Tanaman Budidaya. Jakarta: UI Press.

Salisbury, F. B. (1957). Plant Life. New York: Scientific American Inc.

Salisbury, F. B., \& Cleon, W. R. (1995). Fisiologi Tumbuhan: Biokimia Tumbuhan. Bandung: ITB Press.

Warsa, T \& Cucu, S. A. (1982). Teknik Perancangan Percobaan (Rancangan dan Analisis). Serial Pengenalan Dasar - dasar Statistik Terapan. Bandung: Fakultas Pertanian Universitas Padjadjaran.

Waskom, R. M., Bauder, T. S., Davis, J. G., \& Cardon, G. E. (2003). Diagnosing Saline and Sodic Soil Problems. CSU Cooperative Extension Fact Sheet no. 0.521.
CSU Cooperative Extension, Ft. Collins, CO.

Wareing, P. F., \& Phillips, I. D. J. (1981). Growth And Differentiation In Plants. 3rd edition. Pergamon Press. New York.

Widjaja, Adhi, I. P. G., Subiksa, I. G. M., Sutcipto, P., \& Radjagukguk, B. (1990). Pengelolaan Tanah dan Air Lahan Pasang Surut, Studi Kasus Karang Agung, Sumatera Selatan. Dalam Usaha Tani di Lahan Pasang Surut dan Rawa. Risalah Seminar Hasil Penelitian Proyek Swamps II. Bogor, 19 - 21 September 1989.

Yan, W., Dilday, R., Helms, R., \& Bourland, F. (2004). Effect of Giberrellic Acid on Rice Germination and Seedling Emergence in Stress Condition. Arkansas Agricultural Experiment Station Research Series 517. 303 - 316. 